\title{
The Passivhaus standards of low rise residential building in hot countries: Koya as a case study
}

\author{
W. H. Baiz \\ Architectural Engineering Department, Koya University, Kurdistan, Iraq
}

\begin{abstract}
In recent history, residential housing has improved and spread through the world in different ways. There are reasons for these improvements, such as existing various structures, environmental impacts and building technologies. In many cases, this is to make buildings be more comfortable for living in. Today, people are more careful about the amount of energy that should be used for heating and cooling. These two main cases - more comfort and less energy - encourage the designers to think of achieving them at the same time. So, nowadays, Passivhaus has solved this problem at quite high levels. Also, improving technology can be measured as an important factor in this achievement.

The aim of this project is to research and study, through the previous research and examples, the existing service houses, as well as proposing a sample. Throughout the analysis, the demonstration of building construction will be explained. Following this, the cost and time requirements will be reviewed, and the position in the building, orientations, materials, and the opening area on each floor of the building construction will be considered.

The results of this paper have demonstrated that the way of residential construction impacts on the decreasing use of energy for cooling and heating, making the houses work very well and be more comfortable for living. Otherwise, heating and cooling resources can solve them. In suggestions and the conclusion, there is a summary of the study, with a recommendation.
\end{abstract}

Keywords: Passivhaus, design, ventilations, energy, residential building. 


\section{Introduction}

The Passivhaus is a standard that is used for reducing heat and cool requirement of buildings. It can be applied to hot, cool and moderate climates in any places in the world [1]. Also it can be used for many types of buildings such as residential, non-residential, new and old buildings [2]. Passivhaus developed from a German- Swedish academic collaboration in 1988. The first Passivhaus buildings were completed in 1991 in Darmstadt, Germany. Today, over 9,500 Passivhaus buildings have been realized in Germany, over 2,500 in Austria, and approximately 12,500 worldwide. Despite all of this huge numbers of Passivhaus use around the word, still Kurdistan does not have.

In general, by focusing on the amount energy manually is used in Kurdistan houses, for heating in summer and cooling in the winter, is quite unbelievable. So, for avoiding this cases, which has many advantages like: reducing the cost, more comfortable for live, less energy, applying the Passivhaus standards will be very effective. The Passivhaus standard was initially developed for mid and northern European climates but has been proven to work extremely well in hot climates. High levels of airtightness and insulation work equally well in protecting buildings from overheating provided there is adequate solar shading [3].

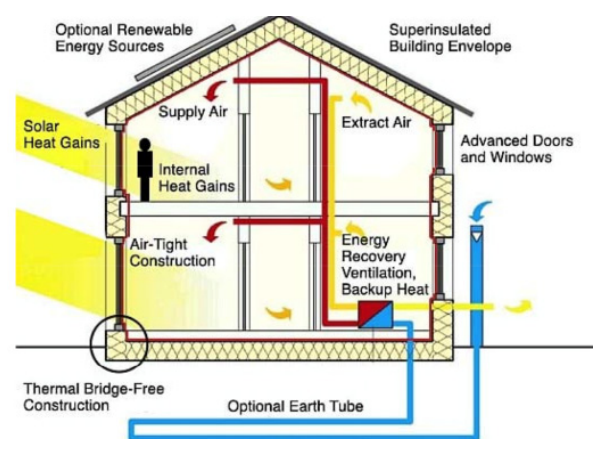

Figure 1: $\quad$ More living comfort, less energy [4].

\section{The principle of the Passivhaus}

The principle of the Passivhaus is that it is a building with no heating system except for the heat recovery through the ventilation unit. If built correctly the buildings are robust, healthy and cost effective. To achieve a Passivhaus, strict design guidelines must be followed in relation to six principles (see figure 2). 


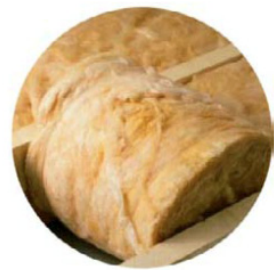

1. Super-insulation

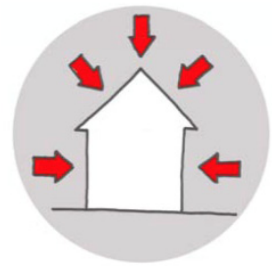

4. Compactness of form

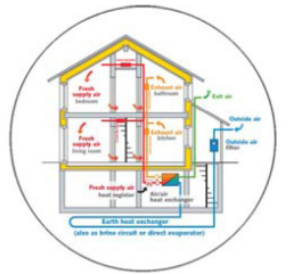

2. MVHR

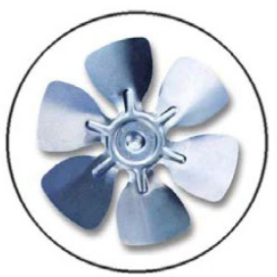

5. Airtightness

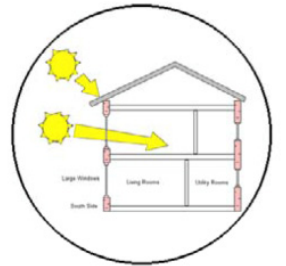

3. Careful exploitation of solar gain

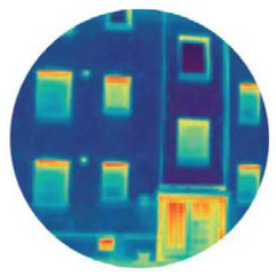

6. Minimise thermal bridges

Figure 2: $\quad$ Principles of Passivhaus [5].

\subsection{Insulation}

\subsubsection{Super-insulation}

For the wall slab and roofs systems, in the Passivhaus standards, there should be super insulations for insulating the inside door from outside doors, at the same time specific windows used in the walls. It means the main purpose of insulation part is to reduce heat transfer through walls, slabs, and roofs.

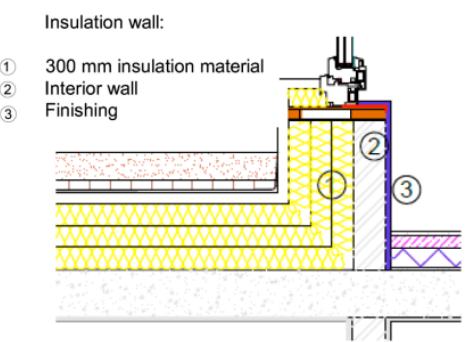

Figure 3:
Insulation example (drawn by the author).

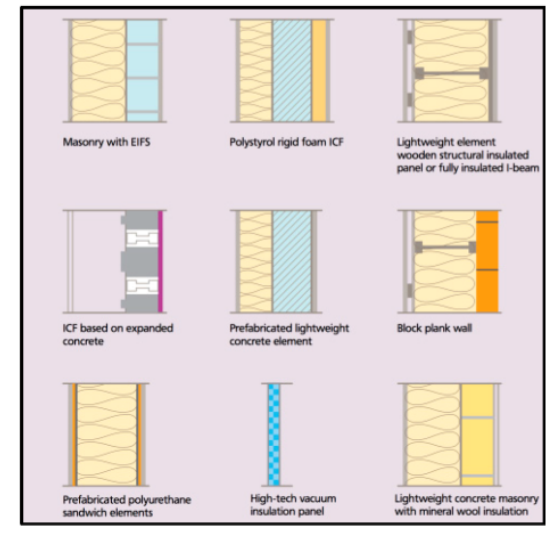

Figure 4: $\quad$ Passivhaus wall constructions [1]. 


\subsubsection{Glazing}

Triple glazes are required for this specific property. It has two different works at the same time: (1) Keeping the inside temperature of building and not letting it go outside; (2) Permitting the sun solar to enter the inside buildings.

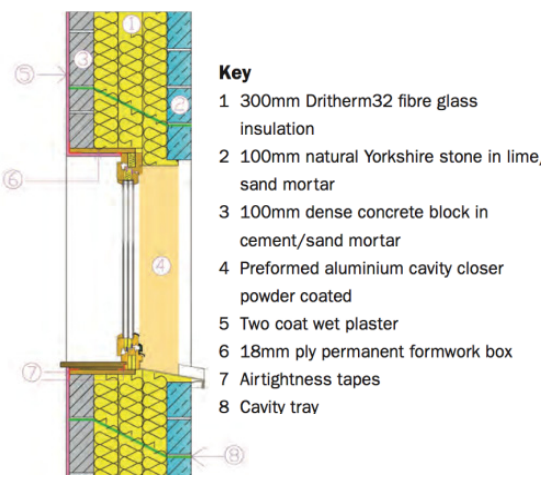

Figure 5: Glazing detail [6].

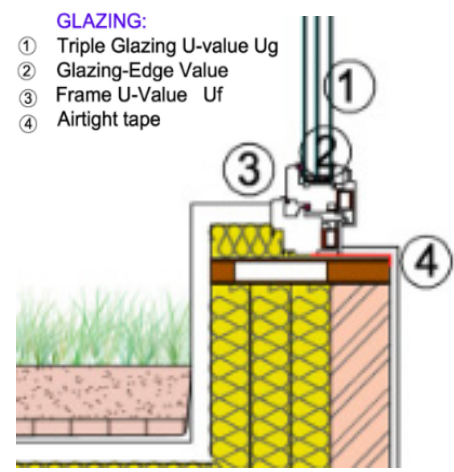

Figure 6: Triple-glazing (drawn by the author).

\subsection{MVHR}

Mechanical ventilation with heat recovery (MVHR) is an absolutely integral component for achieving the necessary performance levels needed for Passivhaus buildings. It allows for sufficient and comfortable ventilation to all areas of the house whilst minimizing the loss of heat gained from the sun, human activity, cooking, showering, electrical appliances and the like. As a rule of thumb, MVHR starts to become economically and environmentally effective when airtightness levels are less than or equal to 3 air changes per hour @ 50 Pascal [6].

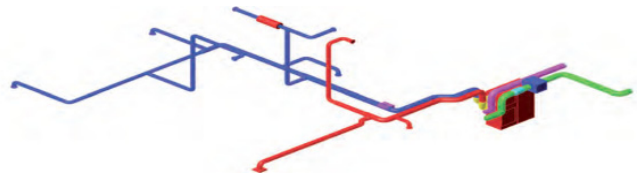

Figure 7: $\quad$ MVHR system [6].

\subsection{Careful exploitation of solar gain}

Orientation is an important point in Passivhaus. In the northern hemisphere, buildings should be oriented to face south as much as possible to get maximum solar gains and day lighting [7]. 


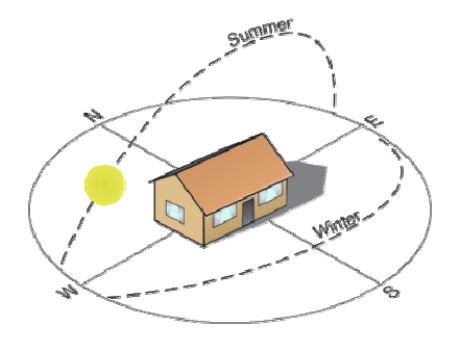

Figure 8: $\quad$ Orientation [4].

\subsection{Compactness of form}

The compactness of the building is a ratio between area (external surface area) and volume (internal building volume) SA/V. In term of Passivhaus, it should be less than $0.7 \mathrm{~m}^{2} / \mathrm{m}^{3}[1]$.

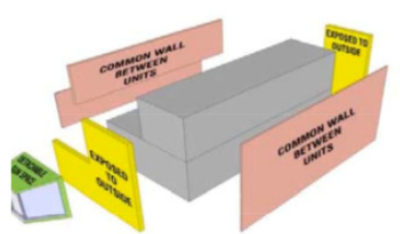

Single Unit SA $/ V=0.14 \mathrm{~m}^{2} / \mathrm{m}^{3}$

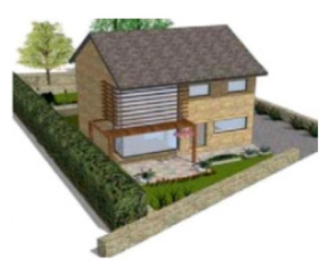

Passivhaus SA/V $=0.64 \mathrm{~m}^{2} / \mathrm{m}^{3}$

Figure 9: $\quad$ Compactness ideal [3].

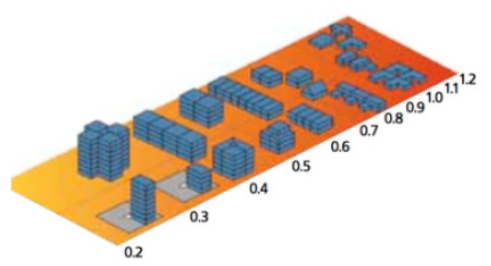

Figure 10: Compactness [5].

\subsection{Airtightness}

Airtightness is crucial to achieving low-energy performance. In the floor and foundations, a crucial area for airtightness is the junction between the concrete slab with walls, where you could get differential movement and so bad airtightness detailing. For the Denby Dale Passivhaus we have taken the slab onto the inner leaf to avoid this problem [1]. 


\subsection{Thermal bridge}

Thermal bridge is another standard of Passivhaus which can be used to avoid unnecessary heat loss in the building. It is usually located outside and it can be seen in three different places such as: facings and surface, facing and floors, balcony and corners of the buildings

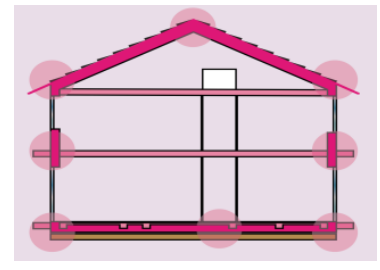

Figure 11: Thermal bridge [1].

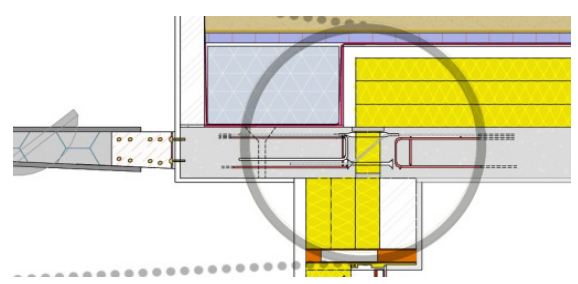

Figure 12: Thermal bridge with solar panel (drawn by the author).

\section{Typical Passivhaus design}

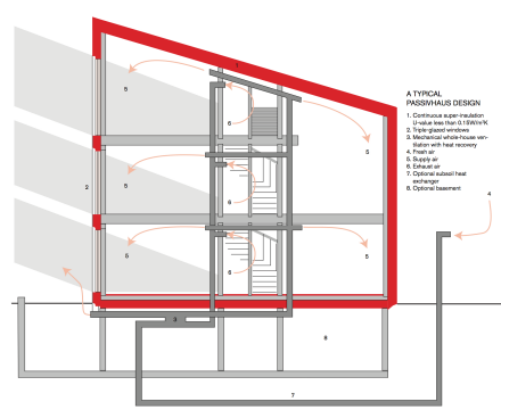

\section{A TYPICAL} PASSIVHAUS DESIGN

1. Continuous super-insulation

$\mathrm{U}$-value less than $0.15 \mathrm{~W} / \mathrm{m}^{2} \mathrm{~K}$

2. Triple-glazed windows

3. Mechanical whole-house ven-

tilation with heat recovery

4. Fresh air

5. Supply air

6. Exhaust air

7. Optional subsoil heat

exchanger

8. Optional basement

Figure 13: $\quad$ Typical design [2].

\section{Conclusions}

It is not easy to pinpoint, exactly, the strengths and weaknesses of specific design and exactly degree of components and other principles of the Passivhaus building. But as an overall, there are common standards for design this type. It is clear that, nowadays, people still think about easy and comfortable live especially inside their home. Having good design and those six principles of these standards, which are high levels of insulation, high quality mechanical ventilation with heat recovery (MVHR), careful exploitation of solar gain, compact design, very high standards of airtightness and minimal thermal 
bridging, make the buildings more effective and more comfortable for live with lees energy used. They way of build and construction needs quite high techniques in some parts, such as a thermal bridge MVHR design and so on. But it does not mean that it is impossible to be built. In the result, the high quality houses can be gated.

\section{Recommendation}

For the suggestion and recommendation in this proposal projects in the Kurdistan, there are many sides and steps for designers and builders can follow it. In difficult cases, especially in Kurdistan, they can do step-by-step. It means stopping from designing and build this type buildings not right because the requirements do not exist or may be difficult to apply it. In this region they can apply what they have ability then step by step apply all. To summarize, there are many points:

- It is true that it is quite difficult to get all the material that are necessary for the Passivhaus or may be expensive to build compare with other common houses, but it can be start step by step. It means getting super insulation may be difficult and for build also, but it is easy to take triple glazing instead of double-glazing.

- Starting with thinking about principles of passive house in the alldifferent types of buildings. Not just residential bit for educations, offices, ministry building and so on.

- Designing and planning master plans of the cities with the taken Passivhaus orientations for dividing and cutting the lands. It means, in Design and planning the city master plan, orientation for all types of typologies should be taken.

- Putting a solar cell on the roofs, as an extra energy source may be MVHR lighting units and may be it needs for cooling when overheating occurs.

\section{References}

[1] BRE References [on line]. Available at: http://www.passivhaus.org.uk/ [Accessed 21 May 2013].

[2] Harmant, H. (2008) Lessons from Abroad, Architects Journal, 28.02.08, pp. 58-63.

[3] http://www.passivhaus.org.uk/page.jsp?id=19 [Accessed 20 July 2013].

[4] http://www.ecowho.com/articles/6/The_importance_of_building_orientation .html [Accessed 13 September 2013].

[5] Oldfield, P. (2012). Beyond Operations: Sustainable Materials and the Growing Importance of Embodied Carbon, K14 MDT/DMT Materials Design and Technology. University of Nottingham, unpublished. 
280 First International Symposium on Urban Development: Koya as a Case Study

[6] Denby Dale Passivhaus - Technical Guide. Green building store 2010 [on line]. Available at: http://www.greenbuildingstore.co.uk/ [Accessed 27 May 2012].

[7] http://www.ecowho.com/articles/6/The_importance_of_building_orientation .html [Accessed 13 September 2013].

[8] http://www.passivhaus.org.uk/page.jsp?id=17 [Accessed 13 June 2013].

[9] Isover Passivhaus Information. Built for the future: The Isover MultiComfort House, Isover 2007. 